\title{
Linking Teacher Professionalism and Learner Autonomy Through Experiential Learning and Task Design
}

\section{Douglas Fleming and Pierre Walter}

Like others in the teaching profession, second language education (SLE) teachers have been subjected in recent years to a process of work intensification and accountability. This process makes use of externally developed sets of behavioral objectives, assessment instruments, commercially produced classroom materials, and externally controlled technologies. Taken together, these have resulted in a marked reduction in the freedom of dedicated SLE teachers to be inventive, flexible, adaptable, and responsive to students' needs. In short, teachers are losing professional autonomy. In this article, we argue that an experiential learning approach can help counter this trend. We describe and compare three theoretical frameworks and models in this orientation that have been developed specifically for SLE and draw out practical implications for classroom task design. We contend that experiential learning is more than a classroom management technique and argue the importance of linking learner autonomy and teacher professionalism through this approach.

Tout comme leurs homologues dans l'enseignement, les enseignants de L2 ont vu, depuis quelques années, leur charge de travail augmenter et l'obligation de répondre de l'exercice de leurs responsabilités s'intensifier. Ce processus s'appuie sur des ensembles d'objectifs comportementaux et des instruments d'évaluation d'origine externe, du matériel pédagogique de production commerciale et des technologies contrôlées de l'extérieur. L'effet cumulatif de ces éléments a été une réduction notable dans la marge de manoeuvre qu'ont les enseignants de L2 dans leur capacité d'invention. leur souplesse, leur faculté d'adaptation et leur sensibilité aux besoins des élèves. En résumé, les enseignants perdent leur autonomie professionnelle. Dans cet article, nous proposons une approche visant l'apprentissage par l'expérience pour contrer cette tendance. Nous décrivons et comparons trois cadres et modèles conceptuels qui vont dans ce sens et qui ont été développés pour l'enseignement en L2. Des conséquences pratiques pour la conception de tâches en salle de classe sont évoquées. Nous affirmons que l'apprentissage par l'expérience n'est pas seulement une technique de gestion de salle de classe et soulignons l'importance de lier l'autonomie de l'apprenant et le professionnalisme de l'enseignant par le biais de cette approche. 


\section{Introduction}

Teaching as a professional activity has been under intense attack in recent years. As has been well documented (Slaughter \& Leslie, 1997; Apple, 1993; Larsen, 1983), the privileges that most educated or intellectual workers have traditionally enjoyed are being steadily eroded. These privileges have included greater control over one's work environment, reflective leisure, flexible working hours, and the ability to engage in professional development. Through a process of intensification, workers with claims to professional status are being subjected to more and more of the kinds of pressures traditionally associated with wage labor such as chronic overloading, a greater reliance on outside expertise, and the systematic use of intensive supervision (usually marketed as accountability).

As Apple and Jungck (1992) have pointed out, teachers have been subjected to the process of intensification through a greater use of externally developed sets of behavioral objectives, assessment instruments, commercially produced classroom materials, and externally controlled technologies. This process has resulted in a marked reduction in preparation time for teachers (Hargreaves, 1994), a trend that has lessened the abilities of dedicated teachers to be inventive, flexible, adaptable, and responsive to students' needs. This trend is no less evident for second-language education (SLE) teachers than for those in other disciplines.

In this article, we argue that an experiential learning approach can counter this trend and greatly enhance teacher professionalism in the current context of SLE. Our practical focus is on classroom task design, which we believe to be a key element in teachers' decision-making processes. We contend that experiential learning is more than a classroom management technique, as Knutson (2003) has intimated. Although Knutson is quite correct in pointing out the importance of tasks in the experiential frameworks that she cites (most notably Koenderman, 2000), the emphasis we wish to place is on learner autonomy and its implications for teacher professional autonomy.

We wish to stress here that we do not argue for the use of experiential learning, learner autonomy, and professionalism for their own sakes. Rather, we believe that these three notions are important factors in our ability to respond to learners' needs and in their struggles for empowerment. Without the strong element of autonomy and professionalism that this approach can facilitate, our programs will be in danger of becoming oppressive, irrelevant, mass-produced, and inefficient. In short, the experiential learning approach is one way to counter the view that "one size fits all" in ESL, an attitude we believe is becoming all too prevalent in our profession.

In the sections below, we first describe the theoretical framework that informs experiential learning approaches in general education. We then present the major elements of each of three experiential learning models that have been developed specifically in reference to SLE. The models are com- 
pared in a separate section below. We conclude by drawing out the practical implications for classroom task design.

\section{Theoretical Foundations of Experiential Learning}

As Kelly (1997) has pointed out, the broad currency of experiential learning has only recently been recognized in SLE despite its longstanding influence in most general education practices since Dewey (1938) and Freire (1989). Experiential learning is generally taken to mean learning by doing, and is often associated with learning that is based on personal experiences outside the institutional setting of schools. The approach had its early roots in the mid19th-century shift from formal, abstract education in schools to practicebased education (Lewis \&.Williams, 1994). Today, familiar forms of experiential learning include internships in medicine, clinical psychology, education, and social work, as well as various forms of cooperative education in businesses, community groups, and government agencies. Adventure or wilderness learning, corporate programs of action learning, and strategic visioning workshops are also popular variations of experiential learning (OED, 2002).

Experiential learning models owe much to Dewey (1938), who included a cycle of learning and experience in his scientific method. According to Dewey, learners become aware of a problem, develop an idea to solve it, try out a response, experience the consequences, and confirm or modify their previous knowledge (Lewis \& Williams, 1994). Freire's (1989) influence on experiential learning was also profound, chiefly through his stress on the importance of problem-posing as a key element in the construction of knowledge. This emphasis is closely related to his criticisms of what he called the banking model of education, the concept that learners are empty vessels into which knowledge is poured and then withdrawn. Both Dewey and Freire believed that learner autonomy was the key to building self-actualizing and emancipated learners capable of transforming society. Although a number of SLE theorists have been influenced by Experiential Learning (most notably Auerbach, 1992; Lantolf, 2000; Lave \& Wenger 1991; Oxford, 1997; Toohey \& Day, 1999), there have been few attempts at a systematic application of the approach in SLE to date.

In general education theory, Kolb (1984) built on Dewey's legacy to theorize on experiential learning cycles and the varied characteristic learning styles to be found in them. Kolb's model posits a four-dimensional cycle of experiential learning in which learners: (a) have some form of concrete experience, (b) reflect on this experience, (c) abstract general rules or concepts from it, and (d) actively experiment with applications of these new concepts, generating new concrete experiences through repetitions of the cycle. The importance of Kolb's work is reflected in the fact that over 1,500 publications have addressed his experiential learning theory. In general education, experiential learning has been popularized in a wide variety of teach- 
ing manuals and resources (Apps, 1991; Borich, 1999; Palmer, 1998; Schön, 1987; Wlodkowski \& Ginsberg, 1995). However, only a handful of these publications are in the field of SLE (Kolb \& Kolb, 2002).

The first of the three models specific to SLE derived from Kolb (1984) that we consider below is the cooperative learning approach to L2 education described by Kohonen $(1992,2001)$. Kohonen takes Kolb's classic general model of experiential learning and develops an L2 acquisition pedagogy around it. The second model, elaborated by Legutke and Thomas (1991) in their book Process and Experience in the Language Classroom, proposes taskbased learning projects as the experiential curriculum for ESL courses. The third model, described by Kenny (1993a, 1993b, 1996), is based on an "experiential syllabus," in which ESL students conduct investigative field research and develop a "piece of work" as the basis of their L2 learning.

\section{Kohonen's Cycle of Experiential Language Learning}

In Kohonen's (1992) application of Kolb's (1984) model to L2 learning (Figure 1), students progress through an experiential L2 learning cycle where they (a) are exposed to "meaningful use of language in natural contexts" (p. 28); (b) make their own observations and reflect on possible rules or generalizations of language usage (awareness of the rules, e.g., go $\rightarrow$ goed); (c) are formally presented with correct usage rules (explicit rules, e.g., go $\rightarrow$ went); and (d)

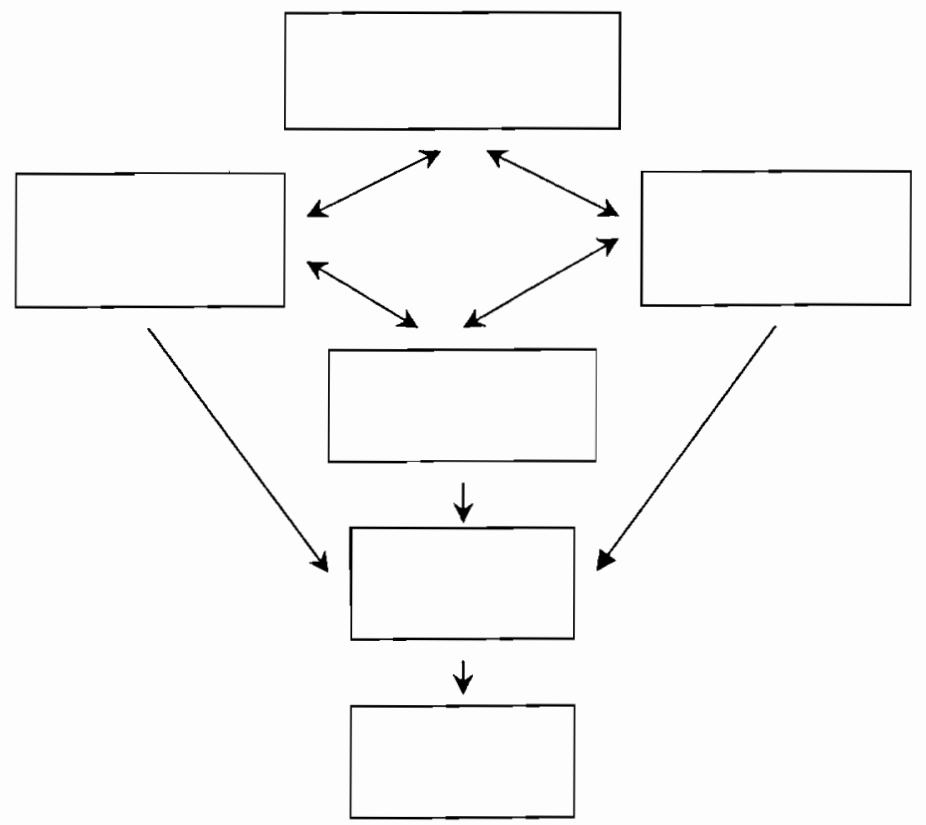

Figure 1. Kohonen's model of experiential L2 learning. Adapted from Kohonen (1992, p. 28). 
experiment with new aspects of language usage employing these rules (new experiential data). Taken together, these processes comprise intake and lead to output.

In the center of the cycle, Kohonen (1992) takes "internal processing of input data" as the L2 learning process. In many ways, Kohonen's model, with its "computerized" vocabulary, portrays L2 learners as somewhat akin to cognitive machines who engage in

a continuous process of recycling input data, aiming at a more sophisticated understanding and incremental automatization of the system. If the meaningful learning process continues, the learner's second language competence will expand and he or she will be able to deal with increasingly complex language data. (p. 29)

With this view of L2 learning in mind, Kohonen then proposes cooperative learning as the means of putting his model into practice in the language classroom. As Kohonen describes it, cooperative learning assures ample "face-to-face interaction, where learners explain, argue, elaborate and link current material with what they have learned previously" (p. 35), offering abundant opportunities and demands for L2 acquisition. Briefly, cooperative learning involves the teacher organizing small groups of students into "learning teams" who undertake highly structured co-operative learning tasks using procedures and topics supplied by the teacher. Group process skills are taught to members before teams begin their tasks, members are often assigned specific group roles, the teacher monitors their progress, and they are periodically asked to assess what they have learned and how they are working together as a team. Kohonen (1992) gives one example of how this might work in practice:

to learn about vocabulary learning strategies, learners might be given various vocabulary lists in L2, which they learn using different types of mnemonic techniques. Explanations of the rationale behind the different techniques will help them to understand why they work and to make personal choices depending on what seems to work best for them. (p. 25)

Regardless of the task, Kohonen (2001) argues that experiential L2 learning should promote: (a) awareness of oneself as a learner, (b) awareness of the learning process, (c) task awareness, (d) teachers' awareness of their own educational philosophies, and (e) the larger culture of the learning institution and society. In his view, these various levels of awareness will then encourage the acquisition of L2 learning strategies as the basis of learner autonomy.

\section{Legutke and Thomas' Task-Based Projects}

Whereas Kohonen's (1992) model-building is fairly instrumental in orientation, placing students into teacher-structured cooperative learning tasks, 


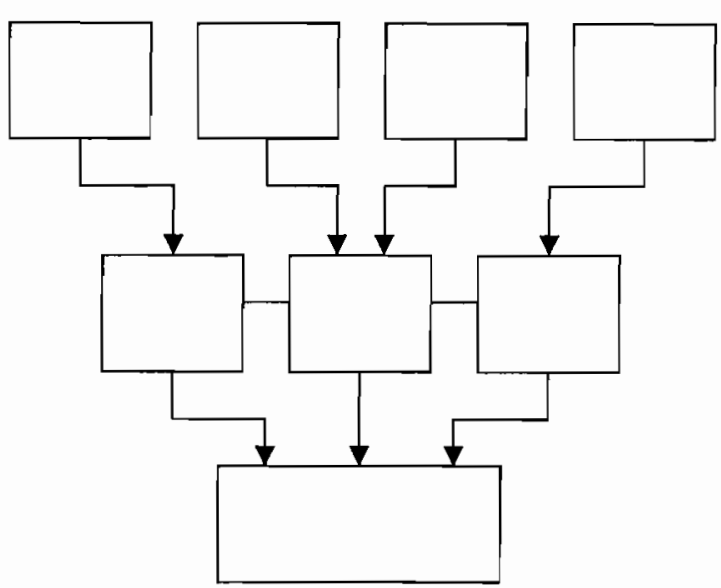

Figure 2. Task construction in Legutke and Thomas' project learning model. Source: Legutke and Thomas (1991, p. 168).

Legutke and Thomas (1991) argue for a more broadly learner-centered approach to experiential language learning, featuring language learning projects as their model of TESL practice. Legutke and Thomas posit the notion of a pyramid of communicative language tasks as the "building bricks" for the larger "target task" (Figure 2). After students and teachers agree on an overriding target task for the class-such as interviewing passengers at an air terminal, teaching a section of an English literature class, or holding a rummage sale-they then work backward from the target task to develop "pre-tasks" building up to it. Both the target task and pre-tasks are jointly determined by students and teachers in an action-planning process aimed at specifying the steps that are needed to accomplish the target task.

Pre-tasks each have a specific objective, ranging from topic information (e.g., doing background research), operational skills (e.g., learning how to use a tape-recorder), contact with native speakers (e.g., making appointments), practicing language in terms of structure, lexis, and skill (e.g., practicing listening comprehension for interviews), or planning and monitoring the process (e.g., reviewing group activities). The nature of tasks, sequencing, and relationships between tasks all depend on the target task.

Legutke and Thomas (1991) identify six stages of a typical project. These serve as a framework to structure the overall action plan leading to the target task. The six project stages are: (a) opening; (b) topic orientation; (c) research and data collection; (d) preparing data presentation; (e) presentation; and (f) evaluation. In brief, the opening stage promotes positive group dynamics and introduces learners to a communicative language approach, the use of multimedia, textual materials, and the "live community" as a resource base for language learning. The topic orientation stage sensitizes learners to the topic, mobilizes their previous knowledge of it, arouses curiosity, and allows 
for the exchange of personal experience. In the research and data collection stage, learners define the nature and extent of project tasks, learn how to collect and record data in the community, research textual data or analyze a literary text, and complete the target task. In stage four, preparing data presentation, learners review, analyze, and decide how to present their data before a live audience for stage five, the presentation of the project. In the last stage, evaluation, learners and teachers assess knowledge gained of the topic, of group and teacher interaction, procedures and materials used, language gains and deficits, examples of learners' work, and possible unintended learning outcomes.

Examples of language learning projects given by Legutke and Thomas (1991), in addition to those mentioned above, include organizing a summer fête, conducting an oral history project at an nursing home, producing and selling an anthology of student poetry, designing a feature film based on a short story or a novel, and drafting a tourist brochure about one's home town. Each of these target tasks, the pre-tasks leading up to it, and the six developmental stages of the learning project are rich in L2 learning integrated across the four skills.

\section{Kenny's Experiential Syllabus}

In many ways, Kenny's (1993b) scheme for experiential learning builds on Legutke and Thomas' (1991) model of project learning, but with greater emphasis on promoting learner autonomy and a specialized focus on the norms, practices, and discourse of academic research. Moreover, rather than seeking to distill the salient characteristics of experiential L2 learning from an amalgamation of case studies across a broad range of ESL settings, as Legutke and Thomas and Kohonen (1992) have done, Kenny focuses on analyzing the theoretical foundations and practices of a single intensive English for Academic Purposes (EAP) program for science and engineering postgraduate students. However, Kenny also offers ample room for the possibility of a wide variety of similar programs, built according to their own particularities on his basic experiential learning model (Walter, 1998; Kenny \& Savage, 1997).

In Kenny's (1993b) model (Figure 3), "preparatory task-based work" in the first half of the EAP program is a means of building up the research tools, ways of thinking, and L2 discourse needed to identify topics for students' pieces of work or investigative research in the second half of the program. Briefly, preparatory tasks involve the analysis and writing of research texts, small-group aural and video interviews of researchers and their work, and the reporting and discussion of results in meetings of the class as a whole.

Preparatory task-based work takes Swales' (1990) Field-Problem-Solution schema for analyzing academic research texts and extends it into a framework for thinking, learning, and communicating about the research process in general. 


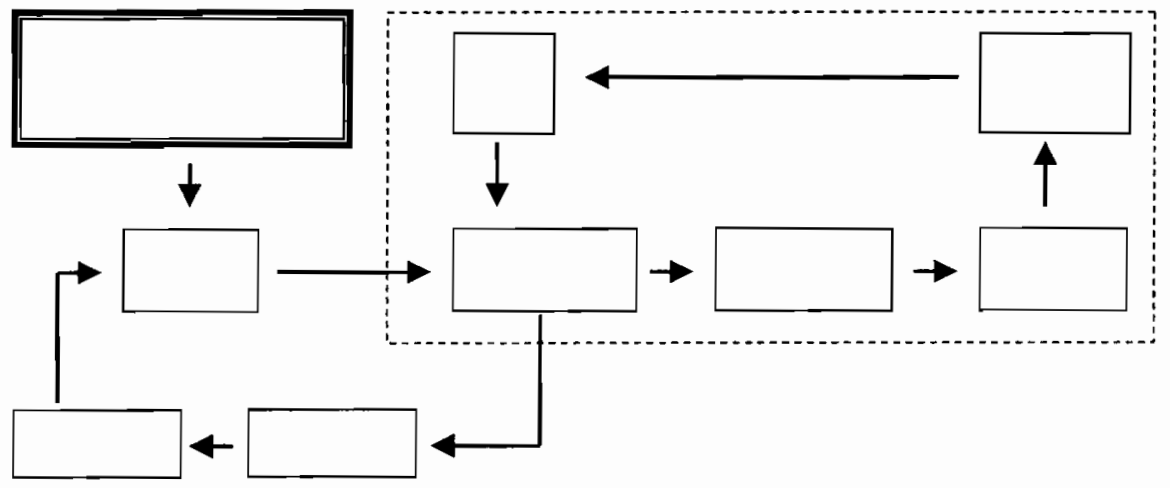

Figure 3. Kenny's scheme for experiential L2 learning. Source: Kenny (1993b, p. 439).

As seen in Figure 3, following preparatory tasks, students identify fields, topics, or themes; clarify them through preliminary research; discover either that they have no real interest in them or that they are excited, engaged, or intrigued by them. In the latter case, if they find a topic of real interest or concern to them, they then plan, carry out, and present investigative research on the topic (pieces of work), discover solutions and new ideas, and realize personal and social growth. In the process, they define new fields of interest, leading to further research and so on through the cycle. Examples of pieces of work reported by Kenny (1993b) include The Effect of Tourism on Forest Environments, Safety on Construction Sites, Making Progress in English, Micropower for Remote Areas, Smoking and Society, and Women Working in a Man's World. The topics students decide to focus on tend to reflect the fields of study in which they will be enrolled as postgraduate students, so this gives them good preparatory L2 grounding for their studies, as well as an introduction to academic research in general. Returning to Figure 3, after preliminary research, if students do not find a topic of real personal concern, their work becomes an exercise with no real meaning outside their desire to fulfill the task, and they begin again to try to identify new topics.

The heart of Kenny's (1993a) approach to experiential learning is that it depends on learner autonomy as its organizing principle, around which the program's "experiential syllabus" is developed. By autonomy, Kenny means not only learners' control over the content and process of learning, but also their expression of "who they are, what they think, and what they would like to do, in terms of work they initiate and define for themselves" (p. 440). With this principle in place, an experiential L2 syllabus can be characterized as follows.

An experiential syllabus is essentially an organization of people. Its participants learn from experience and reflections as they investigate issues 
they have identified as of pressing concern and interest to them ... And as the participants, working in groups, use a great deal of language while doing their work, the gains also include an $\mathrm{L} 1$, an $\mathrm{L} 2$ or even an L3. (pp. 451-452)

The focus in this experiential syllabus is clearly not the teaching of an L2 as the content of the course; rather, students, motivated by their engagement with each other and their pieces of work, learn the academic lexis, grammatical structures, and communicative language skills required to achieve this end. In the process, students make clear and substantial gains both in L2 acquisition and in their capacity for autonomous learning.

\section{Comparing the Three Models}

In considering each of the three above models, we see that they move along a continuum of learner autonomy (Benson, 1997; Holec, 1981), in which L2 students exercise varying amounts of control over their learning. As SLE teachers, the decision of which model we might adopt is dependent not only on our personal philosophies of TESL, professional training, and experience, but also on how much control over our classrooms we are willing to give up, how much risk of the unknown we can tolerate, and how comfortable we are with experimenting in our teaching practice. In addition, of course, there is a host of institutional factors supporting or discouraging innovation in teaching in general. Negotiation between the learners and instructors about task design is difficult, for example, if learners have limited proficiency in the second language or teachers in the first language of the student. Under such conditions, bilingual support, interpretation, and translation are encouraged as a starting point for negotiations on tasks, and might-depending on what is decided by teachers, students and administrators-run throughout the resulting SLE programs developed.

In many ways, the three models of experiential learning in TESL presented above represent varied cultures and philosophies of teaching, distinguished by their different approaches to learner autonomy. Although each has as its central concern the task-based acquisition of communicative language, the latitude given to students to make decisions about what L2 discourses they will acquire and how they will do so varies substantially across the three models. In the first instance, Kohonen (1992) proposes a fairly rigid, teacher-directed approach to the structuring of tasks, which are executed primarily in the L2 classroom. Indeed, the procedures and content of co-operative learning as a teaching technique have been tested, refined, and "packaged" over almost 30 years of research and practice, mostly among schoolchildren. Typical cooperative team learning tasks like Jigsaw (Aronson, Blaney, Stephan, Sikes, \& Snapp, 1978) or Student Teams-Achievement Divisions (Slavin, 1986), although they can be tailored for particular L2 acquisition goals, offer relatively little room for students to innovate, direct 
their L2 learning, or create meanings of their own outside of specified task roles and boundaries. Kohonen (2001) in fact argues that learner autonomy does not come naturally to everyone and that some students prefer teacherdirected approaches.

while a number of students are comfortable with a responsible role as self-organised and autonomous learners, some prefer a more dependent role. They expect the teacher to give them the facts of language and explain mistakes directly rather than asking them to find them out for themselves. (pp. 39-40)

For Kohonen, then, not all students are ready for large measures of autonomy in experiential L2 learning, but may develop this capacity through cooperative learning.

The model of experiential project learning described by Legutke and Thomas (1991) also relies heavily on the experience of teaching children in formal school settings. However, Legutke and Thomas assume that L2 learners have significantly more potential for autonomous learning than does Kohonen. Although project learning, target tasks, and communicative pre-tasks are structured by teachers according to the six stages noted above, the model takes a more broadly humanistic view of L2 learners. This allows students more latitude in decision-making about project topics, content, materials, processes, and the management of learning. In other words, although Kohonen is willing to accede control of learning within the constraints of cooperative learning tasks at the micro-level of cooperative learning tasks, Legutke and Thomas do so at the meso-level of learning projects, allowing students more autonomy both in planning L2 learning experiences and in carrying them out.

Kenny (1996), in contrast to both Kohonen and to Legutke and Thomas, is primarily concerned with issues of learner autonomy in experiential L2 learning for adults. His concept of learner autonomy operates at the macrolevel of an entire ESL program rather than just at the levels of learning projects or communicative L2 tasks. In the intensive EAP program he describes, Kenny clearly begins with the assumption that all L2 learners, given an experiential syllabus of the sort he describes, can and will exercise their autonomy in experiential learning. In the students Kohonen characterizes as passive, Kenny sees at fault a dependence on teacher-direction socialized through past schooling and the "knowledge transmission mode of educational delivery" (p. 453). When confronted with an experiential syllabus, these students look for, but do not find a "proper English teacher" or "proper English lessons," as recognizable (or "real") forms of ESL teaching. This disjuncture is sufficient reason for them to shy away from the experiential L2 learning process, as they have as yet little personal capacity as autonomous learners. 
The notion of doing something, as opposed to being told something by a teacher, has not been a part of their previous educational experience ... these students are suffering from the reified knowledge syndrome, a direct product of too much submission to transmitted knowledge in their earlier education. The students lack focus, do not see the relevance of knowledge to life, have no grasp of knowledge as a resource, or of knowledge-for-use, and are trapped in the knowledge they have while prostrate before that which they feel they lack. (p. 453, italics in the original)

As Kenny $(1996,1993 b)$ further explains, however, as these students move through the experiential syllabus, they almost always shed their notions of reified knowledge, make impressive L2 gains, and come to know themselves better in the process. These outcomes are borne out in long-term evaluations of the EAP program (Walter, 2000).

\section{The Significance of Tasks}

In a study of decision-making processes, Fleming (1998) shows that a group of ESL instructors in a typical work site exhibited a range of attitudes toward professional autonomy over various curricular elements. The teachers in his study clearly wanted quite strongly to retain control over the choice and design of classroom activities. To the instructors involved in this study, an important element in the design of classroom activities was the setting of authentic and realistic learner tasks.

Although the term task has had a long history in general education theory, it is important to note that it was not common to use the term in describing SLE classroom objectives and activities before the late 1980s (Long \& Crookes, 1992). Stern (1983), Ellis (1985), and Howatt (1984), in their authoritative surveys of the field, do not refer to tasks in any great detail, for example. In SLE, the increased use of the term task has been increasingly associated with the communicative approach and assessment. In one of the first discussions of the communicative approach in curriculum design, Johnson (1979) makes the linkage between the two clear by saying,

fluency in the communicative process can only develop within a "taskorientated teaching" - one which provides "actual meaning" by focusing on tasks to be mediated through language, and where success or failure is seen to be judged in terms of whether or not these tasks are performed. (p. 200)

Today, tasks are prominent in most ESL teacher education manuals and course texts (Brown, 2000; Larsen-Freeman, 2000; Ur, 1996). Many SLE scholars have elaborated task-based curriculum models, among these Ellis (2003), Skeehan (1996, 1998, 2002), Long and Crookes (1992), Breen (1987), and Nunan (1988). 
Tasks have also been significant elements developed in many of the recent curriculum and assessment benchmark projects undertaken by national governments (Brindley, 1985). In fact, Canada has been one of the leaders in this respect, as is reflected in the emphasis placed on tasks by the federally sponsored Canadian Language Benchmarks (Pawlikowska-Smith \& Citizenship and Immigration Canada, 2000). Similarly, the federal Centre for Canadian Language Benchmarks (2004) makes great use of tasks in the examples of lesson plans that its provides on its Web site.

In terms of professional autonomy, such externally generated standards and tasks are arguably inefficient and oppressive. In our view, teachers should be able to create their own tasks for activities tailor-made for the learners they face. Clearly, the setting of external assessment standards expressed in terms of classroom tasks can erode professional autonomy and lead to a one-size-fits-all tendency in SLE. This is not to say that externally produced lesson plans and tasks are not valuable as heuristic learning devices, for example, in the education of new teachers or those inexperienced in task-based approaches. However, the building of a basic professional competence in learning to design tasks effectively and creatively also requires opportunities and freedom for teachers to practice doing this. In short, external standards and tasks work against the development of this teaching competence.

The determination of tasks also has important implications for learners. Individual and contextual differences are often submerged in national curriculum documents that treat varied educational contexts and learner groups in a common manner (Moore, 1997). Tasks that are exciting for one group of learners can become oppressive hurdles for others. Local context and individual life worlds will determine the relevance of a given set of tasks to specific groups of learners and so on.

As we argue in our comparison of the three models above, the particular experiential learning approach taken can lead to the development of tasks that facilitate or discourage learner autonomy to varying degrees. However, all approaches have at their heart a SLE curriculum centered on the internal development of tasks together with students. As such, we offer here a counterpoint of creative possibilities to more teacher-centered classroom management techniques.

\section{Conclusion}

The three models discussed in this article embody varied theoretical perspectives on how TESL classes and programs might be designed around experiential learning. In their respective publications, Kohonen (2001, 1992), Legutke and Thomas (1991), and Kenny (1996, 1993a, 1993b) offer a set of principles and practical examples that we believe are useful for SLE teachers. We trust that through our discussion, those of us who are currently using or experimenting with experiential approaches in the classroom will recognize 
the solid theoretical underpinnings of this work. In addition, we hope that the discussion here will contribute to further developments in linking learner autonomy and our own professionalism. In doing so, we will be engaged in experiential learning ourselves: in experimenting, observing, and reflecting on results; in making meaning of our profession as SLE teachers.

\section{Note}

${ }^{1}$ Kenny's focus on rather open-ended problem-posing activities negotiated among students and teacher owes much to earlier work by Breen and Candlin (1980) on the process syllabus in language education (Breen, 1984; Candlin, 1987). Our thanks to an anonymous reviewer for bringing this to our attention.

\section{Acknowledgments}

Our thanks to the editors and the anonymous reviewers of the TESL Canada Jourmal for their many insightful suggestions.

\section{The Authors}

Douglas Fleming is a doctoral candidate at UBC in the Department of Language and Literacy Education and teaches ELSA/LINC for the Surrey School District.

Pierre Walter is an assistant professor in the Department of Educational Studies at the University of British Columbia.

\section{References}

Apple, M. (1993) Official knowledge: Democratic education in a conservative age. New York: Routledge.

Apple, M.W., \& Jungck, S. (1992). You don't have to be a teacher to teach this unit: Teaching, technology and gender in the classroom. American Educational Research Journal, 27, 227-251.

Apps, J. (1991). Mastering the teaching of adults, Malabar, FL: Kreiger.

Aronson, E., Blaney, N., Stephan, C., Sikes, J., \& Snapp, M. (1978). The jigsaw classroom. Beverly Hills, CA: Sage.

Auerbach, E. (1992). Making meaning, making change: Participatory curriculum development for adult ESL literacy. McHenry, IL: Delta Systems.

Benson, P. (1997). Philosophy and politics of learner autonomy. In P. Benson \& P. Voller (Eds.), Autonomy and independence in language learning (pp. 18-34). London: Longman.

Borich, G. (1999). Effective teaching methods. Englewood Cliffs, NJ: Prentice-Hall.

Breen, M. (1984). Process syllabuses for the language classroom. In C.J. Brumfit (Ed.), General English syllabus design (pp. 47-60). Oxford, UK: Pergamon.

Breen, M. (1987) Contemporary paradigms in syllabus design. Language Teaching 20, 157-174.

Breen, M., \& Candlin, C. (1980). The essentials of a communicative curriculum in language teaching. Applied Linguistics 1(2), 89-112.

Brindley, G. (1995). Assessment and reporting in language learning programs: Purposes, problems and pitfalls. Paper Presented at the international conference on Testing and Evaluation in Second Language Education, Hong Kong University of Science and Technology.

Brown, H.D. (2000). Teaching by principles. New York: Barnes and Noble.

Candlin, C.N. (1987). Towards task-based language learning. In C. N. Candlin \& D. Murphy (Eds.), Lancaster practical papers in English language education. Vol. 7. Language learning tasks (pp. 5-22). Englewood Cliffs, NJ: Prentice Hall.

Centre for Canadian Language Benchmarks (2004). Samples of CLB lesson plans. Retrieved February 24, 2004, from http:/ / www.language.ca/LessonPlans.html 
Dewey, J. (1938). Experience and education. New York: Collier Books.

Ellis, R. (1985). Understanding second language acquisition. Toronto, ON: Oxford University Press.

Ellis, R. (2003) Task-based language learning and teaching. Oxford, UK: Oxford University Press.

Fleming, D. (1998). Autonomy and agency in curriculum decision making: A study of instructors in a Canadian adult settlement ESL program. TESL Canada Journal, 16(1), 19-35.

Freire, P. (1989). Pedagogy of the oppressed. New York: Continuum.

Hargreaves, A. (1994). Changing teachers, changing times: Teachers work and culture in the post-modern age. Toronto, ON: OISE Press.

Holec, H. (1981). Autonomy and foreign language learning. Oxford, UK: Pergamon Press.

Howatt, A.P.R. (1984). A history of English language teaching. Oxford, UK: Oxford University Press.

Johnson, K. (1979). Communicative approaches and communicative processes. In C. Brumfit \& K. Johnson (Eds.), The communicative approach to language teaching (pp. 192-205). New York: Oxford University Press.

Kelly, C. (1997). David Kolb, The Theory of Experiential Learning, and ESL. Internet TESL Journal, 3(9).

Kenny, B. (1993a). Investigative research: how it changes learner status. TESOL Quarterly, 27, 217-231.

Kenny, B. (1993b). For more autonomy. System, 21(4), 431-442.

Kenny, B. (1996). Knowledge, experience and language teaching. System, 24(4), 449-460.

Kenny, B., \& Savage, W. (Eds.). (1997). Language in development: Teachers in a changing world. London: Longman.

Knutson, S. (2003). Experiential learning in second language classrooms. TESL Canada Journal, $20(2), 52-64$

Koenderman, M. (2000). Monitor training manual. Unpublished manuscript. Sherbrooke, QC: English Language Summer School, Université de Sherbrooke.

Kohonen, V. (1992). Experiential language learning: Second language learning as cooperative learning. In D. Nunan (Ed.), Collaborative language learning and teaching (pp. 14-39). Cambridge, UK: Cambridge University Press.

Kohonen, V. (2001). Towards experiential language education. In V. Kohonen, R. Jaatinen, P. Kaikkonen, \& J. Lehtovaara (Eds.), Experiential learning in foreign language education (pp. 8-60). London: Longman.

Kolb. A., \& Kolb, D. (2002). Experiential learning theory bibliography. Retrieved January 14, 2004, fromhttp://www.learningfromexperience.com $/ \mathrm{html} / \mathrm{research}$ library.html

Kolb, D.A. (1984). Experiential learning: Experience as the source of learning and development. Englewood Cliffs, NJ: Prentice Hall.

Lantolf, J.P. (2000). Sociocultural theory and second language learning. New York: Oxford University Press.

Larsen, N. (Ed.). (1983). The discourse of potver: Culture, hegemony, and the authoritarian state. Minneapolis, MN: Institute for the Study of Ideologies and Literature.

Larsen-Freeman, D. (2000). Techniques and principles in language teaching. Oxford, UK: Oxford University Press.

Lave, J., \& Wenger, E. (1991). Situated learning: Legitimate peripheral participation. New York: Cambridge University Press.

Legutke, M., \& Thomas, H. (1991). Process and experience in the language classroom. London: Longman.

Lewis, L.H., \& Williams, C.J. (1994). Experiential learning: Past and present. New Directions for Adult and Continuing Education 62, 5-16.

Long, M.H., \& Crookes, G. (1992). Three approaches to task-based syllabus design. TESOL Quarterly, 26, 27-55.

Moore, H. (1997). Telling what is real: Competing views in assessing ESL development. Linguistics and Education, 8, 189-228. 
Nunan, D. (1988). The learner-centred curriculum: A study in second language teaching. Cambridge, UK: Cambridge University Press.

OED. (2002). Outdoor Education Directory. Retrieved January 14, 2004, from http://www.ael.org/eric/oed/

Oxford, R.L. (1997). Co-operative learning, collaborative learning, and interaction: Three communicative strands in the language classroom. Modern Language Journal, 81, 443-456.

Palmer, P. (1998). The courage to teach. San Francisco, CA: Jossey-Bass.

Pawlikowska-Smith, G., \& Citizenship and Immigration Canada. (2000). Canadian language benchmarks 2000. Ottawa: Centre for Canadian Language Benchmarks.

Schön, D. (1987). Educating the reflective practitioner. San Francisco, CA: Jossey-Bass.

Skehan, P (1996). A framework for the implementation of task-based instruction. Applied Linguistics, 17(1), 38-62.

Skehan, P. (1998). Task-based Instruction. Annual Review of Applied Linguistics, 18, 268-286.

Skehan, P. (2002). A non-marginal role for tasks. ELT journal, 56, 289-295.

Slavin, R. (1986). Using student team learning (3rd ed.). Baltimore, MD: Center for Research on Elementary and Middle Schools, Johns Hopkins University.

Slaughter, S., \& Leslie, L. (1997). Academic capitalism. Baltimore, MD: Johns Hopkins University Press.

Stern, H.H. (1983). Fundamental concepts of language teaching. Oxford, UK: Oxford University Press

Swales, J. (1990). Genre analysis: English in academic and research settings. Cambridge, UK: Cambridge University Press.

Toohey, K., \& Day, E. (1999). Language-learning: The importance of access to community. TESL Canada Journal, 17(3), 40-53.

Ur, P. (1996). A course in language teaching: Practice and theory. New York: Cambridge University Press.

Walter, P. (1998). Experiential learning in language education: Suggestions for practice. Prospects: A Journal of Australian TESL, 13(1), Pp. 53-67.

Walter, P. (2000). Evaluating language acquisition and learner autonomy in an Asian EAP program. Asian Journal of English Language Teaching, 10, 137-148.

Wlodkowski, R.J., \& Ginsberg, M.B. (1995). Diversity and motivation: Culturally responsive teaching. San Francisco, CA: Jossey-Bass. 